УДК: 658

\title{
ЕКОНОМІЧНА БЕЗПЕКА ПІДПРИСМСТВА:ЕВОЛЮЦІЯ ВИЗНАЧЕННЯ, СКЛАДОВІ, ЗАГРОЗИ
}

\author{
Гладух М.В., здобувач (УкрДУЗТ)
}

В статті розглянуто розвиток, поняття та аналіз економічної безпеки підприємства. Проаналізовано стан захищеності від внутрішніх та зовнішніх загроз. Виділено складові економічної безпеки, розглянута еволючія та визначені загрози, ризики та головні цілі економічної безпеки підприємства. Визначено щуо поняття економічної безпеки дозволяє зрозуміти, щзо сучасні підприємства, знаходячись в різних ситуаціях, змушені приймати ризикові рішення для попередження загроз та небезпек.

Ключові слова: економічна безпека,аналіз, загрози внутрішні та зовнішні, ризики, еволюція, підходи

\section{ЭКОНОМИЧЕСКАЯ БЕЗОПАСНОСТЬ ПРЕДПРИЯТИЯ: ЭВОЛЮЦИЯ ОПРЕДЕЛЕНИЯ, СОСТОВЛЯЮЩИЕ, УГРОЗЫ}

\author{
Гладух М.В., соискатель (УкрГУЖТ)
}

В статье рассмотрено развития, понятия и анализ экономической безопасности предприятия. Проанализировано состояние защищенности внутренних и внешних угроз. Выделены составляющие экономической безопасности, рассмотрена эволючия и определень угрозы, риски и главные целей экономической безопасности предприятия. Определено, что понятие экономической безопасности позволяет понять, что современные предприятия, находясь в разных ситуациях вынуждены принимать рисковые решения для предупреждения угроз и опасностей.

Ключевье слова: экономическая безопасность, анализ, угрозы внутренние и внешние, риски, эволюция, подходы

\section{ECONOMIC SECURITY OF COMPANIES; THE EVOLUTION OF DEFINITION, COMPONENTS AND THREATS}

\section{Gladuh M.V., degree-seeking student (USU of RT)}

The article is about the development and analysis of the concept of economic security. The author had analyzed the state of protection against internal and external threats and identified components of economic security, examined the evolution and determined his own views about threats, risks and main goals of economic security. It was determined that modern companies in variety of different situations need to take risky decisions to prevent threats and possible dangerous. One of the main goals of economic security is to ensure its stable and the most effective functioning nowadays and high potential for development in the future.

Keywords: economic security, analysis, internal and external threats, risk, evolution, development, effective.

Постановка проблеми. Економіка України все більше відстає від економіки розвинутих країн. Проведення неадекватної політики, реформування всіх галузей держави, відсутність конкурентоздатного науковотехнічного потенціалу, залежність від техніки, технологій фінансових структур розвинутих країн посилило без того тяжкі положення самої країни та суб'єктів господарської діяльності. Тому дослідження основних чинників економічної безпеки, виявлення негативних факторів та їх вплив на діяльність підприємств 
$€$ пріоритетним питанням для забезпечення умов економічного зростання потенціалу підприємств різних форм власності.

Аналіз останніх досліджень і публікацій. Спочатку поняття економічної безпеки розглядалось, як забезпечення умов збереження комерційної таємниці та інших таємниць підприємства. Забезпечення економічної безпеки вважалось насамперед перед усіма як захист інформації i тому присвячено багато публікацій. На думку А.Сміта [1], узгодженість стабільності економічної безпеки $€$ функція "невидимої руки ринку“, а безпека учасників ринку, що діють раціонально є природним риском. Шаваєв А.Г. [2] під економічною безпекою підприємств розуміє найбільше ефективне використання ресурсів для запобігання загроз та забезпечення стабільного функціонування підприємства на сьогоднішній час i в майбутньому. Ярочкин В.I. [3] визначає систему безпеки, як організовану сукупність спеціальних органів, служб, коштів, методів та заходів, які забезпечують захист життєво важливих інтересів особистості та підприємства від внутрішніх та зовнішніх загроз. Забродський В.А.[4] трактує поняття економічної безпеки підприємств, як «кількісну та якісну характеристику властивості підприємства відображати здатність «самовиживання» та розвиток в умовах виявлення зовнішніх та внутрішніх загроз». Ковальов Т. і Сухорукова Т.[5], розуміють економічну безпеку підприємства, як стан захищеності діяльності підприємства від негативного впливу зовнішнього оточення, а також здатність своєчасно усувати різноманітні загрози або пристосуватися до існуючих умов, які не відбиваються негативно на його діяльності. Дубецька С.П.[6] пропонує розглядати економічну безпеку підприємства, як стан об'єкта в системі його зв'язків 3 точки зору його стійкості та розвитку в умовах внутрішніх i зовнішніх загроз, непередбачуваних дій та складно прогнозованих чинників. Л.І.Абалкин [7] розглядає економічну безпеку підприємства, як сукупність умов та факторів, які забезпечують незалежність незалежність економіки, стабільність та стійкість, здатність постійного оновлення та самовдосконаленню. Грунін О.А., Грунін С.О.[8] трактують економічну безпеку підприємства, як захищеність діяльності від негативного впливу зовнішнього середовища, а також різні варіанти загроз чи пристосуванні до існуванні умов, які не позначаються на діяльність

Проте аналіз джерел дозволяє зробити висновок, що в економічній літературі відсутня єдність поглядів учених щодо визначення сутності поняття

« економічна безпека підприємства».

Метюю даної статті є дослідження та аналіз поняття економічної безпеки підприємства, розгляд еволюції поняття та визначення власних поглядів i визначення поняття, загроз, ризиків та головних цілей економічної безпеки підприємства.

Виділення невирішених частин загальної проблеми. Поняття «Економічна безпека» пройшло чимало переосмислень у зв'язку зі зміною умов зовнішнього середовища i 3 урахуванням факторів, які зумовлюють процеси управління. Вперше поняття «Економічна безпека» почало застосовуватись на Заході у зв'язку зі зростанням проблеми обмеженості ресурсів та розпадом колоніальної системи, що призвело до порушення традиційних зв'язків між постачальниками ресурсів, життєво необхідних індустріальним суспільствам.

Економічна безпека як наука в Україні зародилась на початку 90-х років минулого століття і розглядалась науковцями 3 позиції захисту комерційної таємниці підприємства. В подальшому досліджуючи дане поняття вчені - економісти почали виділяти зовнішні впливи на економічну безпеку підприємства, а саме термін «економічна безпека» трактувати, як захищеність економічних інтересів підприємства від впливу несприятливих умов зовнішнього середовища.

Вчені - економісти виділили шість етапів розвитку еволюції економічної безпеки підприємства:

- Перший етап розвитку почався 3 1991 по 1997 рр. Загроза економічної безпеки підприємства виникала зі сторони персоналу підприємства , який міг розголосити його комерційну таємницю.

- Другий етап розвитку охоплює 1998 та 1999 рр. Поняття «Економічна безпека підприємства» почали розглядати, як можливий негативний вплив на його діяльність зовнішнього середовища.

- Третій етап розвитку почався 31999 
по 2002 рр. Для цього періоду характерний розгляд цього поняття 3 позиції окремих аспектів діяльності підприємства.

- На четвертому етапі, який співпадає за часом з третім, тобто з 1999 по 2002 рр., вчені виділили функціональні складові економічної безпеки підприємства, а загрози починають розділяти на зовнішні та внутрішні.

- П'ятий етап охоплює період з 2002 по 2005 pp. На цьому етапі розвитку економічна безпека підприємства ототожнюється 3 ефективним його функціонуванням у ситуації ризику. Ризик це важливий елемент підприємницької діяльності. Основна риса характеру підприємця - нахил до ризику.

- Шостий етап почався у 2005 році і триває по цей час. Його особливістю є розгляд економічної безпеки підприємства в залежності від його галузевої приналежності, а загрози економічної безпеки підприсмства розглядаються, як зовнішні так і внутрішні середовища підприємства.

Отже, розглянувши етапи розвитку еволюції поняття економічної безпеки підприємства, можна детальніше зосередитись на окремих питаннях.

До видів загроз економічної безпеки підприємств відносяться внутрішні та зовнішні загрози.

Внутрішні загрози включають в себе:

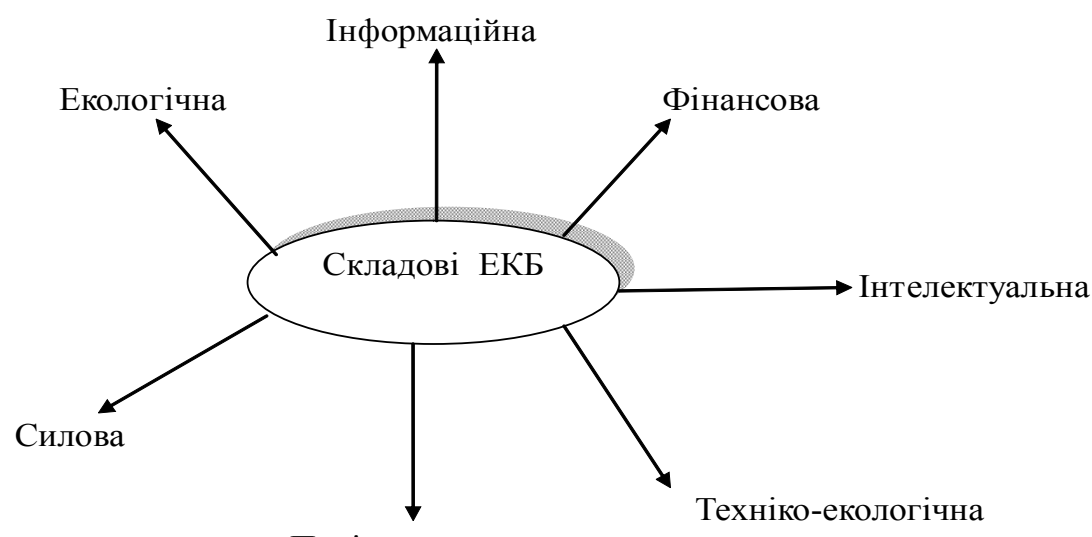

Політико-правова

Рис. 1. Основні функціональні складові економічної безпеки підприємства

Фінансова складова вважається провідною й вирішальною для ефективного функціонуванню підприємства та включаю в себе наступні ризики:

- ризик змін матеріали, енергоресурси і т.д.;
- протиправні чи інші негативні дії персоналу суб'єкта підприємницької діяльності, що загрожують функціонуванню та розвитку підприємства;

- порушення порядку використання технічних засобів;

- низький рівень кадрового, організаційно-правового, інформаційноаналітичного забезпечення управління потенційними ризиками.

До зовнішніх загроз відносять:

- роботу служб безпеки суб'єктів підприємницької діяльності, як вітчизняних так i зарубіжних, 3 метою пригнічення конкурентів, заволодіння ринками збуту чи майном конкурентів;

- протиправну діяльність організованих злочинних формувань та окремих осіб з метою заволодіння майном суб'єктів підприємницької діяльності;

- роботу спеціальних служб іноземних держав, щодо здобуття інформації про економічні процеси у сфері підприємництва 3 метою здійснення анти конкурентних заходів.

По-друге, треба розглянути економічну безпеку підприємства 3 боку чинників підприємницьких ризиків. Основними напрямами організації економічної безпеки підприємства $є$ окремі функціональні складові (Схема 1): 
дебітором боргів;

- ризик неможливості погашення кредиторської заборгованості;

- ризик, пов'язаний зі зміною курсу валюти;

- ризик, пов'язаний зі змінами цін на обладнання;

- ризик, пов'язаний 3 падінням купівельної спроможності грошей;

- ризик, пов'язаний зі знецінюванням активів підприємства, нестачею оборотних коштів;

$$
\text { ризик, пов'язаний }
$$
неплатоспроможністю покупця.

Техніко-технологічна

складова передбачає аналіз ринку технологій стосовно виробництва продукції аналогічного профілю певного підприємства та включає в себе наступні ризики:

- ризик появи у конкурентів нової технології виробництва з меншими витратами;

- ризик відсутності уваги до впровадження інновацій, заохочувальних заходів щодо винахідництва та раціоналізаторства 3 боку керівництва підприємства;

- ризик, пов'язаний 3 неефективністю інноваційної діяльності підприємства;

- ризик, пов'язаний 3 відсутністю технологічних змін;

- ризик, пов'язаний $з$ позаплановими простоями обладнання;

- ризик нераціонального використання виробничих потужностей.

Екологічна складова повинна гарантувати безпеку суспільству від суб'єктів господарювання, що здійснюють виробничокомерційну діяльність. Вона включає в себе наступні ризики:

виробництва;

- ризик, пов'язаний 3 шкідливістю

- ризик, пов'язаний $з$ надзвичайними i аварійними ситуаціями;

- ризик, пов'язаний зі збільшенням гранично допустимої концентрації шкідливих викидів;

- ризик, пов'язаний із забрудненням навколишнього середовища;

- ризик втрати здоров'я працівником підприємства через невідповідність умов праці існуючим нормативам;

- ризик недостатнього забезпечення відповідності екологічності виробництва

затвердженим

нормативним

актам.

Інтелектуальна та кадрова визначає інтелектуальний та професійний склад кадрів та включає в себе наступні ризики:

- ризик несанкціонованого використання інтелектуальної власності підприємства 3 корисливою метою;

- ризик викрадення дизайнерських ідей ;

- ризик втрати інтелектуальної власності підприємства;

- ризик морального зносу інтелектуального капіталу;

- ризик відсутності креативного типу мислення, професіоналізму працівників;

- ризик недостатності інтелектуального потенціалу для інвестування;

- ризик зниження питомої ваги інженерно-технічних працівників і науковців у загальній кількості працюючих;

- ризик зниження раціоналізаторської та винахідницької активності.

Інформаційна складова формується на здійснення збіру всіх видів інформації і та аналізу отриманої інформації 3 дотриманням загальноприйнятих принципів. Вона включає в себе наступні ризики:

- ризик відсутності або недостатності економічних досліджень та використання їх результатів;

- ризик недостатнього рівня забезпечення необхідною для роботи інформацією за обсягом, якістю і своєчасністю надання;

- ризик помилки при зборі інформації;

- ризик несанкціонованих дій по знищенню, спотворенню, блокуванню інформації;

- ризик зовнішніх і внутрішніх атак на інформаційну безпеку підприємства;

інформації.

ризик заволодінням носіями

Політико-правова складова охоплює в себе аналіз загроз негативних впливів; оцінку поточного рівня забезпечення; планування комплексних заходів спеціалізованими підрозділами підприємства; здійснення ресурсного планування; планування роботи відповідних функціональних підрозділів підприємства. Ця складова включає в собі такі ризики :

- ризик, пов'язаний зі страйками, народними хвилюваннями; 
енергоносії;

- ризик, пов'язаний зі зміною цін на

- ризик, пов'язаний зі зміною політичної ситуації в країні;

- ризик, пов'язаний 3 відносинами 3 повноважними органами;

- ризик, пов'язаний 3 політичними особливостями регіону, де розташоване виробництво;

- ризик, пов'язаний 3 незапланованими обмеженнями господарської діяльності підприємства з боку держави;

- ризик порушення штрафних санкцій;

- ризик зростання процентних ставок за кредитами, неконтрольованої грошової емісії, інфляційних процесів, нестабільності валюти та грошової політики.

Силова складова економічної безпеки підприємства в програмі антикризового господарства має забезпечити фізичну та моральну безпеку співробітників;гарантувати безпеку майна та капіталу підприємства; гарантувати безпеку інформаційного середовища підприємства;забезпечити сприятливе зовнішнє середовище бізнесу.

Проведене дослідження дозволило виявити суттєві відмінності щодо переліку таких складових й трактування їх суті. Так, З.Варналій [9], О.Ареф'єв [10] і Т.Кузенко [10.1] у складі економічної безпеки підприємства виділяють: фінансову, інтелектуальну, техніко-технологічну, правову, ресурсну, екологічну, інформаційну, силову. В.Бокій [11] включає до складу економічної безпеки технологічну, ресурсну, фінансову та ринкову. І.П.Отенко [12] та інші автори виділяють фінансову, інтелектуальну, кадрову, техніко-технологічну, правову, інформаційну, екологічну та силову складову.

На думку автора, економічна безпека підприємства — це:

1. стан захищеності усіх систем підприємства при здійснені господарської діяльності в певній ситуації;

2. стан всіх ресурсів підприємства (капіталу, трудових ресурсів, інформації, технологій, прав) та підприємницьких здібностей, при якому можливий найефективніший $\mathrm{i}$ динамічний науковотехнологічний та соціальний розвиток, здатність запобігати або швидко вирішувати внутрішні та зовнішні загрози;

- стан соціально-технологічної системи підприємства, який дає змогу уникати зовнішніх загроз i протистояти внутрішнім чинникам дезорганізації за допомогою наявних ресурсів, підприємницьких здібностей менеджерів.

До функцій основних цілей економічної безпеки підприємства належать:

- забезпечення високої фінансової ефективності роботи, фінансової стійкості та незалежності підприємства;

- $\quad$ забезпечення

технологічної

незалежності та досягнення високої конкурентоспроможності технічного потенціалу суб'єкта господарювання;

- досягнення високої ефективності менеджменту, оптимальної та ефективної організаційної структури управління підприємством;

- досягнення високого рівня кваліфікованого персоналу та його інтелектуального потенціалу;

- мінімізація руйнівного впливу результатів виробничо-господарської діяльності на стан навколишнього середовища;

- якісна правова захищеність усіх аспектів діяльності підприємства;

- забезпечення

захисту

інформаційного поля, комерційної таємниці і досягнення необхідного рівня інформаційного забезпечення роботи всіх підрозділів підприємства;

-ефективна організаційна безпека персоналу підприємства, його

капіталу та майна, а також комерційних інтересів.

Однією із головних цілей економічної безпеки підприємства $\epsilon$ забезпечення його стійкого i максимально ефективного функціонування сьогодні та забезпечення високого потенціалу розвитку та зростання підприємства у майбутньому. Для найбільшого ефективного використання корпоративних ресурсів підприємства, необхідно досягнути шляхом запобігання загрозам та негативних впливів на економічну безпеку підприємства.

Сутність економічної безпеки полягає у забезпеченні поступального економічного розвитку суспільства 3 метою виробництва необхідних благ та послуг, що задовольняють індивідуальні та суспільні потреби.

Також головна мета економічної безпеки підприємства полягає в тому, щоб гарантувати його стабільне та максимальне

Вісник економіки транспорту і промисловості № 51, 2015 
ефективне функціонування зараз i високий потенціал розвитку в майбутньому. Всередині будь-якого підприємства повинна бути своя система безпеки, забезпеченням функціонування якої будуть зайняті кілька департаментів.

Для забезпечення інформаційної безпеки треба використовувати внутрішні документи, що регламентують доступ до цілих категорій інформації, до комерційної таємниці; доступ до різного виду інформації надається в залежності від посади, а в деяких випадках, за прізвищами. Сучасні підприємства мають повністю електронний документообіг, сайти в Інтернеті, мобільні додатки, клієнтські форми. Це означає, що важливим елементом, якого раніше не було, стає забезпечення Інтернет безпеки як клієнтів так i співробітників організації, підприємства тощо. Мова йде про захист персональних даних (місце розташування, телефони, номери карт, пошукові запити та інше ), які стають відомі відвідувачам сайтів.

Сучасний світ таїть безліч загроз для економічної безпеки підприємств i тому підприємство повинно ретельно стежити за всіма факторами. На нашу думку треба приділяти більше уваги персоналу підприємства, компанії для запобігання шахрайства, а саме треба вести внутрішні нормативні документи та інструкції, кодекс корпоративної етики та інші правила, які чітко роз'яснюють співробітнику поведінку в тій чи іншій ситуації. Сьогодні великі компанії, підприємства для забезпечення економічної безпеки використовують психологічне тестування кандидатів і співробітників, тести визначення благонадійності тощо.

Висновки.

Підсумовуючи вищезазначене, у широкому розумінні економічна безпека підприємства - це система, яка забезпечує можливість попередження різних загроз, захищаючи економічні інтереси підприємства. Виникає потреба в удосконаленні методичного забезпечення, узагальнення наявних підходів до поняття « економічна безпека підприємства». Визначення поняття економічної безпеки дозволяє зрозуміти, що сучасні підприємства, знаходячись в різних ситуаціях, змушені приймати ризикові рішення для попередження загроз та небезпек.

\section{СПИСОК ЛІТЕРАТУРИ}

1.Смит А. Исследование о природе и причинах богатства народов.- М.:ЭКСМО, 2007. - c. 443 .

2.Шаваев А.Г. Безопасность корпораций. Криминологические, уголовноправовые и организационные проблемы. М. « Банковский деловой центр», 2004.- 42 с

3.Ярочкин В.И. Служба безопасности фирмы. М.: «Ось- 89», 1997.

4.Д. Ковалев, Т. Сухорукова Экономическая безопасность предприятия // Экономика Украины, 1998г, №5.- с. 48-52.

5.Дубецька С. П. Економічна безпека підприємства України / С. П. Дубецька // Недержавна система безпеки підприємництва як суб'єкт національної безпеки України: Збірник наук.-практ. конф., Київ, 16-17 травня 2001 р. - К.: Вид-во Європейського ун-ту фін, інформ. систем, менедж. і бізнесу, 2003. - С. 146-172.

6.Варналій 3. Проблеми i шляхи забезпечення економічної безпеки України/ 3. Варналій // Екноміка і управління.- 2001.- №1.c. 18-29.

7.Абалкин Л.I. Економічна безпека Росії: загрози та їх от ображення // Питання економіки.-1994.-№12

8.Грунін О.А., Грунін С.О. Еконмічна безпека підприємства. СПб.: Питер, 2002. 160 с.

9.Сумець О.В.-Стратегія підприємства. Теорія, ситуації, приклади: Навч. посібник- К. : ВД “Професіонал”, 2005.- 354 с.

10.Ареф'єва О. В. Планування економічної безпеки підприємств / О. В. Ареф'єва, Т. Б. Кузьменко. - К.: Вид-во Європ. ун-ту, 2005. - 170 с.

11.Бокій В. I. Економічна безпека підприємства - найважливіша складова фінансової стійкості / В. І. Бокій // Актуальні проблеми економіки. - 2003. - № 8. - С.111114.

12. Економічна безпека підприємства : навчальний посібник / укл. І.П. Отенко, Г.А. Іващенко, Д.К.Воронков. - Х. : Вид. ХНЕУ, 2012 - с.45 (Укр. мов.)

Рецензент д.е.н., професор УкрДУЗТ Дейнека О.Г. Експерт редакційної колегії к.е.н., доцент УкрДУЗТ Сухорукова Т.Г.

Вісник економіки транспорту і промисловості № 51, 2015 